Research Article

\title{
Solvent Extraction of Jatropha Oil for Biodiesel Production: Effects of Solvent-to-Solid Ratio, Particle Size, Type of Solvent, Extraction Time, and Temperature on Oil Yield
}

\author{
Justin W. Ntalikwa \\ The University of Dodoma, College of Earth Sciences and Engineering, Department of Petroleum and Energy Engineering, \\ P.O. Box 259, Dodoma, Tanzania
}

Correspondence should be addressed to Justin W. Ntalikwa; jntalikwa@yahoo.com

Received 22 April 2021; Accepted 21 July 2021; Published 28 July 2021

Academic Editor: Abdurrahman Saydut

Copyright (C) 2021 Justin W. Ntalikwa. This is an open access article distributed under the Creative Commons Attribution License, which permits unrestricted use, distribution, and reproduction in any medium, provided the original work is properly cited.

The aim of this study was to examine the effects of solvent-to-solid ratio, particle size, extraction time, and temperature on the extraction of Jatropha oil using three organic solvents, i.e., n-hexane, petroleum ether, and ethanol. The Soxhlet extraction method was used, and the parameters were varied in the following ranges: extraction temperature of $24-80^{\circ} \mathrm{C}$, extraction time of 2 to $8 \mathrm{~h}$, solvent-to-solid ratio of $4: 1$ to $7: 1$, and particle size of $0.5-0.8 \mathrm{~mm}$. After obtaining optimal conditions, a large volume of Jatropha oil was prepared, purified, and subjected to analysis of quality parameters. It was found that the oil content of the Jatropha curcas L. seeds used was $48.2 \pm 0.12 \% \mathrm{w} / \mathrm{w}$. The highest oil yield of $47.5 \pm 0.11 \% \mathrm{w} / \mathrm{w}$ corresponding to an oil recovery of $98.6 \pm 0.3 \% \mathrm{w} / \mathrm{w}$ was obtained with $n$-hexane under the following conditions: solvent-to-solid ratio of $6: 1$, particle size of $0.5-0.8 \mathrm{~mm}$, extraction time of $7 \mathrm{~h}$, and extraction temperature of $68^{\circ} \mathrm{C}$. This was followed by that of petroleum ether $(46.2 \pm 0.15 \% \mathrm{w} / \mathrm{w})$ and lastly by ethanol $(43 \pm 0.18 \% \mathrm{w} / \mathrm{w})$. The quality parameters of the oil extracted compared favorably well with most of the values reported in the literature, suggesting that the oil was of good quality for biodiesel production. Environmental and safety concerns over the use of hexane pose a great challenge. Thus, ethanol, which is environmentally benign, is recommended for application. The conditions for ethanol extraction that gave high oil yield were as follows: extraction temperature of $70^{\circ} \mathrm{C}$, extraction time of $7 \mathrm{~h}$, solvent-tosolid ratio of $6: 1$, particle size of $0.5-0.8 \mathrm{~mm}$, and oil yield of $43 \pm 0.18 \% \mathrm{w} / \mathrm{w}$ corresponding to an oil recovery of $89.2 \pm 0.4 \% \mathrm{w} / \mathrm{w}$.

\section{Introduction}

Energy is a primary input to any socioeconomic development. Consequently, as mankind strives towards attaining this development, the energy consumption also grows faster to catch up with the required infrastructure and increase in population. For instance, the global fuel consumption was about 13,205 million tons of oil equivalent (Mtoe) in 2010, and this value is projected to increase by $56 \%$ to about 20,664 Mtoe by $2040[1,2]$ due to the aforementioned reasons. The global energy consumption is mainly from fossil fuels and nuclear energy. In 2019, the total global energy use from these two sources accounted for about $88.6 \%$ amongst which crude oil consisted of $33.1 \%$, coal $27 \%$, natural gas $24.2 \%$, and nuclear $4.3 \%$, whereas the contributions of the hydropower and renewable energies were very small accounting for $6.4 \%$ and $5 \%$, respectively [3]. The observed increasing demand for fossil fuels, their future dearth, global warming, environmental pollution, and energy security issues have driven the world to search for newer, safer, cleaner, and sustainable sources of energy.

Renewable energy sources such as biofuel production is considered to be one of the best alternatives to address the above challenge. However, production of biofuel from edible vegetable oils has been associated with conflicts of need for land and other environmental resources for the production of food. In addition, the high cost of edible feed stocks reduces the economic viability of the biofuel. Thus, the use of nonedible raw materials such as Jatropha curcas Linnaeus is an alternative that can overcome this challenge. Jatropha curcas L. plant (Figure 1(a)) is a multipurpose, droughtresistant plant belonging to the family of Euphorbiaceae. Its seeds (Figures 1(b) and 1(c)) provide nonedible lipids, and 


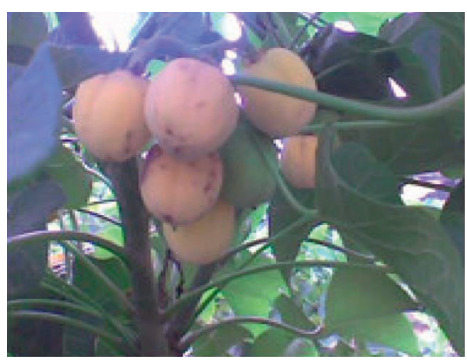

(a)

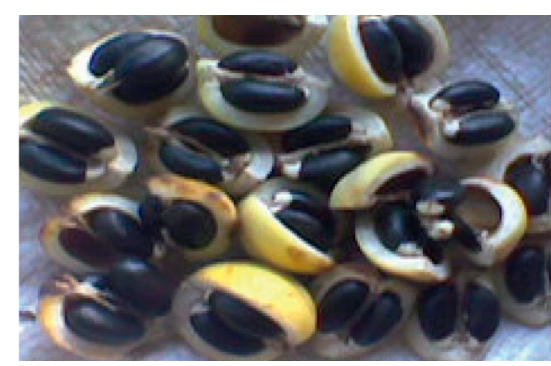

(b)

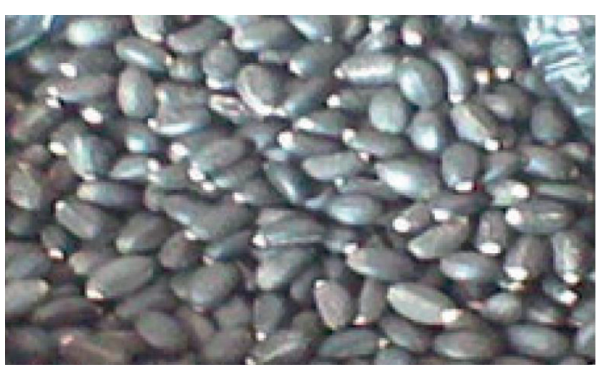

(c)

Figure 1: (a) Jatropha curcas L. tree with ripe fruits, (b) Jatropha curcas L. seeds with their shells, and (c) Jatropha curcas L. seeds with their husks.

hence, they do not contravene food security. This property makes the plant suitable for application in biodiesel production that can be used in transport, industrial, and agricultural sectors, thus positively contributing to the solutions of the challenges facing the energy sector. The oil content of the seeds is approximately $30-46 \% \mathrm{w} / \mathrm{w}$, and this makes their use as an energy source for fuel production very attractive [4-7]. In addition to this, Jatropha oil has been found to have other useful applications such as in the manufacture of candles, soap, cosmetics, and also medicinal purposes [8-10].

Various methods for recovering oil from the seeds have been investigated; these include mechanical, chemical (solvent), supercritical, and enzyme-based extractions. Mechanical extraction methods have been reported to provide oil recoveries in the range of $55 \%$ to $75 \%$ with operating pressure in the range of $20-70 \mathrm{MPa}$. [7, 11-13]. In order to improve the oil recovery, preheating the feed material to $60-120^{\circ} \mathrm{C}$ and the application of twin screw presses with operating pressure in the range of $5-25 \mathrm{MPa}$ have been studied and oil recoveries in the range of $60-90 \%$ have been reported [14-18]. The main drawbacks of mechanical extraction methods are that some amount of oil remains in the cake and sufficient amount of pressure needs to be raised to allow the oil to flow from the solid matrix. Supercritical, ultrasonication, and enzyme-based extraction methods have been studied by many researchers, and oil recoveries reported span in the range of 70-91\% [19-21].

Solvent extraction methods have been reported to provide improved oil recoveries in the range of 90 to $99 \%$ [21-26]. The oil recovery by using this method depends on many parameters such as the type of the solvent used, reaction time, temperature, particle size of the meal, and solvent-to-meal ratio. This is a mass transfer operation, which involves transport of solvent to the solid matrix, dissolution of the solute (oil) into the solvent phase, and transport of solute and solvent from the solid matrix to the bulk fluid. Thus, the concentration gradient of the solute between the solid and the bulk fluid is the determining factor. To attain this, the choice of the solvent that can dissolve the solute and transport is very important and that at the end the two must be easily separated.

Jatropha curcas L. oil can be transformed via acid- or base-catalyzed transesterification reactions to biodiesel. The biodiesel obtained normally has desired physiochemical and performance characteristics comparable to the conventional diesel (petro-diesel) and hence suitable for applications in transportation industry (vehicles, trucks, and trains) and other diesel engines with very minimum modifications. In this context, it is important to explore the feasibility of largescale production of biodiesel from Jatropha oil and thereby provide a solution to manifestation of the current world energy crisis and subsequently improve energy security.

The main objective of this study was therefore to evaluate the performance of the three organic solvents (n-hexane, petroleum ether, and ethanol) on the extraction of Jatropha oil from the seeds. The effects of solvent-to-solid ratio, particle size, type of solvent, extraction time, and temperature on the oil recovery were specifically targeted for investigation.

\section{Materials and Methods}

The seeds of Jatropha curcas l. (Figures 1(a) to 1(c)) were collected from Dodoma municipality in Tanzania. Dodoma is located at $6^{\circ} 10^{\prime} 23^{\prime \prime} \mathrm{S} 35^{\circ} 44^{\prime} 31^{\prime \prime} \mathrm{E}$ at an elevation of $1,120 \mathrm{~m}$ above the sea level, and it has semiarid climate with average low temperature of $16.5^{\circ} \mathrm{C}$ and average high temperature of $28.8^{\circ} \mathrm{C}$, relative humidity of $53-70 \%$, and average rainfall per year of $606.96 \mathrm{~mm}$. The shells and husks of the seeds were cracked and carefully removed to get the inner kernels. The kernels were grinded with a sieve plate and a shaker grinder by using 0.5 and $0.8 \mathrm{~mm}$ sieve plates. The meals were categorized into three particle size classes: below $0.5 \mathrm{~mm}$ (powder size), $0.5-0.8 \mathrm{~mm}$ (coarse size), and above $0.8 \mathrm{~mm}$. The maximum extractable oil from the seeds was then determined as per the procedure described by Jonas et al [6].

Fifty grams of meal was extracted with $350 \mathrm{~mL}$ of the three types of solvents, namely, petroleum ether (b.p. $66^{\circ} \mathrm{C}$ ), ethanol (b.p. $79^{\circ} \mathrm{C}$ ), and n-hexane (b.p. $68^{\circ} \mathrm{C}$ ). All chemicals used were of analytical grade. Extraction time was varied from 2 to $8 \mathrm{~h}$ in a Soxhlet apparatus. The extraction temperature was varied from $24^{\circ} \mathrm{C}$ (room temperature) to the boiling point of the solvent. The solvent-to-solid ratio was varied from $4: 1$ to $7: 1$, and the meal size was fixed at three sizes, i.e., $0.5,0.5-0.8$, and above $0.8 \mathrm{~mm}$. These parameters were varied one at a time to identify the optimum conditions for each type of solvent. At the end of the extraction, the 
micelle was filtered using vacuum filtration to remove suspended solids. Subsequently, the solvent was separated from the oil using a rotary vacuum evaporator and was collected in the receiving flask. The oil, which remained in the sample flask after the process, was weighed and recorded. The oil yield and the oil recovery were calculated using the following equations:

$$
\begin{aligned}
\text { oil yield (\%) } & =\frac{M_{o}}{M_{S}} \times 100, \\
\text { oil recovery }(\%) & =\frac{\text { oil yield }}{\text { oil content in the seed }}=\frac{M_{o}}{M_{S}} \times \frac{1}{S_{o}},
\end{aligned}
$$

where $M_{O}$ is the mass of oil recovered $(\mathrm{g}), M_{S}$ is the mass of solid (meal) used (g), and $S_{O}$ is the oil content in the seed (\% sw/w).

After obtaining optimal conditions, a large volume of Jatropha oil was extracted, purified, and subjected to characterization as per standard testing procedures to ascertain its suitability for biodiesel production. In all experiments, three replicates were used.

\section{Results and Discussion}

3.1. Oil Content of the Seeds. The oil content of the seeds was determined and found out to be $48.2 \pm 0.12 \% \mathrm{w} / \mathrm{w}$, which was slightly higher than the range of $30-46 \% \mathrm{w} / \mathrm{w}$ reported by other researchers [4-7]. This could be attributed to the fact that the genus of Jatropha has about 70-175 species, among them are J. curcas, J. pohliana, and J. gossypiifolia that produce seeds with high oil content [27]. The mass balance suggests that the total oil content of the seeds should be determined so that it can be used for the estimation of appropriate oil recovery according to equation (2). Nevertheless, most of the studies in the literature are reported without the determination of the oil content of the seeds under investigation, hence making it difficult in determining the actual oil recovery.

3.2. Effect of Extraction Temperature. The oil yield increases with the increase in extraction temperature and appears to have a maximum value at the boiling point of the solvent of which beyond this point, the oil yield decreases (Figure 2). When using hexane as a solvent, the amount of extracted oil increased to around $1.5 \%$ by increasing the extraction temperature from $24^{\circ} \mathrm{C}$ to $45^{\circ} \mathrm{C}$ and from $45^{\circ} \mathrm{C}$ to $60^{\circ} \mathrm{C}$. Extraction at boiling point $\left(68^{\circ} \mathrm{C}\right)$ gives an oil yield of about $47.5 \pm 0.11 \% \mathrm{w} / \mathrm{w}$, which is about $2.3 \%$ higher than at $60^{\circ} \mathrm{C}$. Using equation (2) and $S_{O}=0.482$ (determined in this work), the $47.5 \pm 0.11 \% \mathrm{w} / \mathrm{w}$ oil yield translates to $98.6 \pm 0.3 \% \mathrm{w} / \mathrm{w}$ oil recovery, which is in good agreement with that reported by Qian et al [23] who reported an oil recovery of $98 \% \mathrm{w} / \mathrm{w}$ while working with $n$-hexane and ethanol as a cosolvent. Atabani et al. [25] give an oil recovery in the range of $95-99 \% \mathrm{w} / \mathrm{w}$ when using hexane. A similar trend was observed with petroleum ether and ethanol, which gave maximum oil yield of $46.2 \pm 0.15 \% \mathrm{w} / \mathrm{w}$ and $43.0 \pm 0.18 \% \mathrm{w} /$ $\mathrm{w}$ at around their boiling points of $66^{\circ} \mathrm{C}$ and $79^{\circ} \mathrm{C}$,

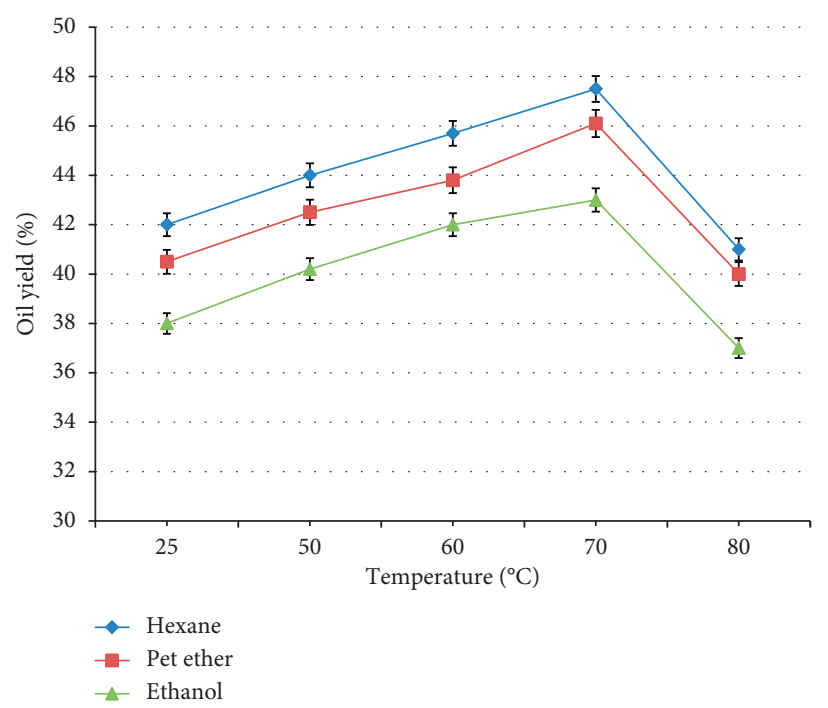

Figure 2: Effect of extraction temperature on oil recovery; extraction time $8 \mathrm{~h}$.

respectively. This observation generally suggests that the solubility of the solute (oil) in the solvent increases with the increase in temperature, hence giving high rate of extraction at high temperature. The upper limit of the temperature in this study was observed to be the boiling point of the solvent, and beyond this point, the oil recovery significantly dropped (Figure 2), and this was certainly due to the boiling off of the solvent. In addition, hexane shows higher oil yield followed by petroleum ether and lastly by ethanol (Figure 2).

3.3. Effect of Extraction Time. The oil yield increases with increase in the extraction time for all solvents studied; however, after $6 \mathrm{~h}$ of extraction time, the curves appear to be flat, indicating that there is no significant increase in oil yield after $7 \mathrm{~h}$ (Figure 3). This suggests that, for the solvents studied, almost all of the oil is extracted after $7 \mathrm{~h}$.

3.4. Effect of Solvent-to-Solid Ratio. Figure 4 shows the effect of solvent-to-solid ratio on the oil yield, where it can be noted that the oil yield increases as the amount of solvent increases and that hexane appears to provide better yield as compared to the other two solvents studied. At solvent-tosolid ratio of $6: 1$, the oil yield appears to reach maximum of $47.5 \%, 46.2 \%$, and $43 \% \mathrm{w} / \mathrm{w}$ for hexane, petroleum ether, and ethanol, respectively. Sayyar et al [28] while working on similar oil extractions reported oil yields of $47.3 \%$ and $46 \%$ $\mathrm{w} / \mathrm{w}$ for $\mathrm{n}$-hexane and petroleum ether, respectively, for solvent-to-solid ratio of $6: 1$ and $8 \mathrm{~h}$ extraction time. Slightly higher values of optimum oil yields have been reported by Keneni et al. [24] (48.29\% w/w), Adeyinka [22] (56.69\% w/w), and Yusuff [29] (56.69\% w/w) while working with $n$-hexane for the similar materials. These variations could be due to the various cultivars of Jatropha plant. Increasing the solvent-to-solid ratio to $7: 1$ does not improve significantly the oil yield (Figure 4). This suggests that the solvent-to-solid ratio of $6: 1$ is optimal for the solvents studied in this work. 


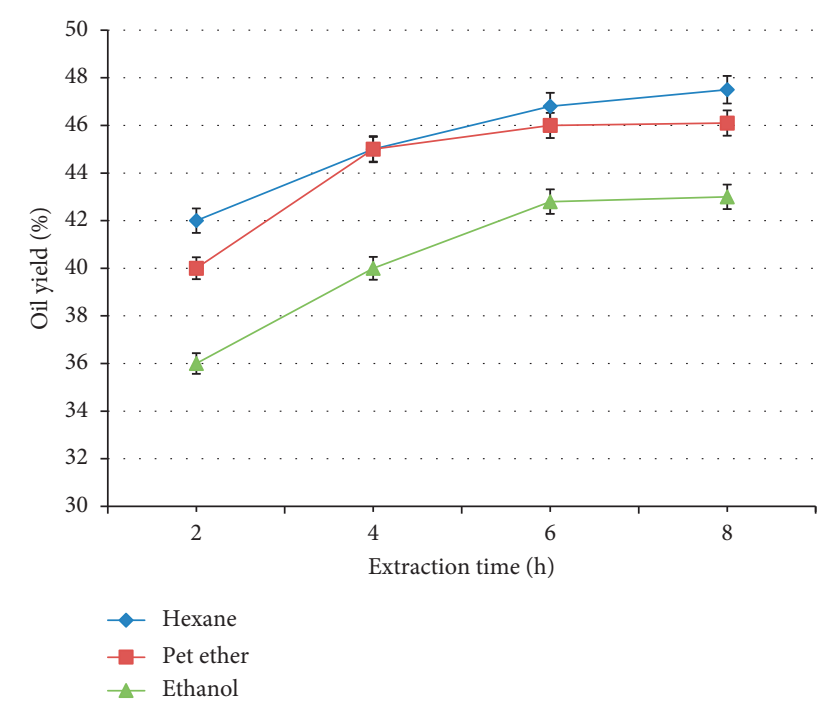

FIGURE 3: Effect of extraction time on oil recovery; extraction temperature $70^{\circ} \mathrm{C}$.

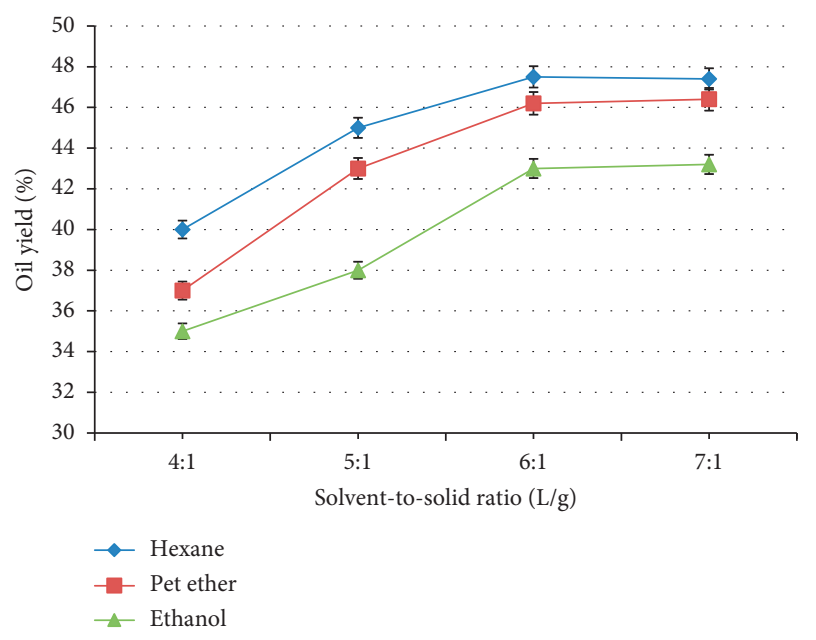

FIGURE 4: Effect of solvent-to-solid ratio.

Based on these results, it can be said that increasing the solvent-to-solid ratio to a specific limit (in this case is $6: 1$ ) increases the oil yield and this is due to the increase in the concentration gradient between the solid and the liquid phases, which favors improved mass transfer.

3.5. Effect of Particle Size on Oil Recovery. Particle sizes within the range of $0.5-0.8 \mathrm{~mm}$ were observed to provide high oil yield for all solvents studied (Figure 5 ). The oil yield from large particles (greater than $0.8 \mathrm{~mm}$ ) was low; this is certainly because large particles have smaller surface area and hence less contact area. This makes it difficult for the solvent to diffuse into the inner part of particle, and hence, less amount of oil can be leached out from the inner part of the particle to the surrounding solution. Using this observation, it was expected that the smaller particles (less than

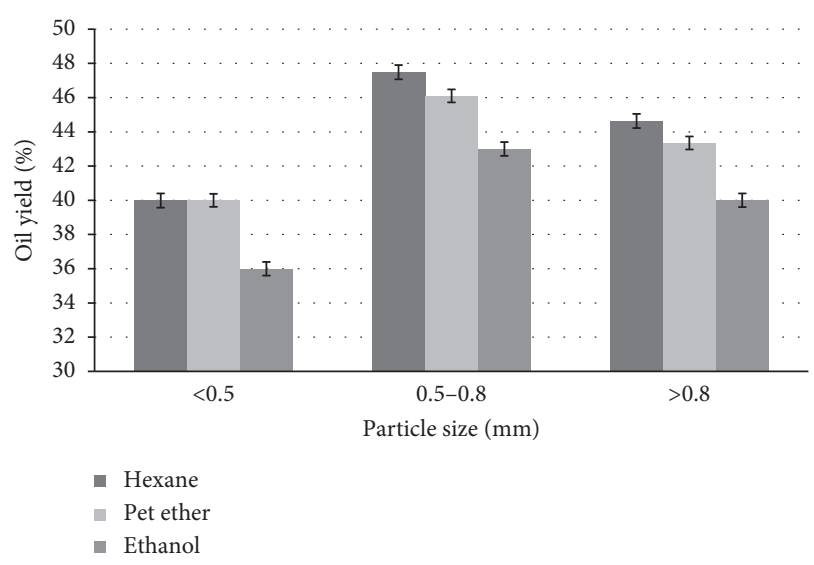

FIGURE 5: Effect of particle size on oil recovery.

$0.5 \mathrm{~mm}$ ) would provide highest oil yield as they have a large surface area and hence a large contact area and very minimal resistance of solvent diffusion into the inner part of the particle. However, the oil yield for these particles was $40 \% \mathrm{w} /$ $\mathrm{w}$ for hexane and petroleum ether and $36 \% \mathrm{w} / \mathrm{w}$ for ethanol. This observation was probably due to the agglomeration of fine particles, which reduces the effective surface area available for the free flow of solvent to the solid. It is, therefore, apparent that small particles of Jatropha seeds tend to stick together and form agglomerates that prevent free interaction between the solid and the solvent. From this study, particle sizes in the range of $0.5-0.8 \mathrm{~mm}$ were observed to be suitable for solvent extraction of Jatropha seeds.

3.6. Effect of Type of Solvent. Out of the three solvents investigated, hexane was observed to be favorable for the extraction of oil from Jatropha seed with an oil yield of $47.5 \%$ w/w (Figure 6). This is also in line with Zimilar et al. [30] who reported oil yields in the range of $41.2-56.7 \% \mathrm{w} / \mathrm{w}$ when using vortex-assisted $n$-hexane extractions of Jatropha oil. There are many factors that contribute to the suitability of the solvent for extracting a particular component. Among them include selectivity (separation factor), distribution coefficient, insolubility, recoverability, chemical reactivity, interfacial tension, density, viscosity, vapour pressure, flammability, and cost. Density and viscosity are required to be sufficiently low for the solvent to travel freely in the solid matrix and leach out the oil. Thus, n-hexane having low dynamic viscosity $(0.3 \mathrm{mPas})$ and low dielectric constant (1.88) appear to penetrate the meal matrix well and leach out the oil as compared to the other solvents (Table 1). Ethanol having slightly high dynamic viscosity $(1.074 \mathrm{mPas})$ and dielectric constant (24.60) appear to have less efficiency as compared to the nonpolar solvents. This augments the discussion above that physical parameters such as density, viscosity, and polarity of the solvent may have significant effect on oil yield, and hence, they should be critically considered in selecting solvents required in oil extraction so as to maximize yield and maintain oil quality. 


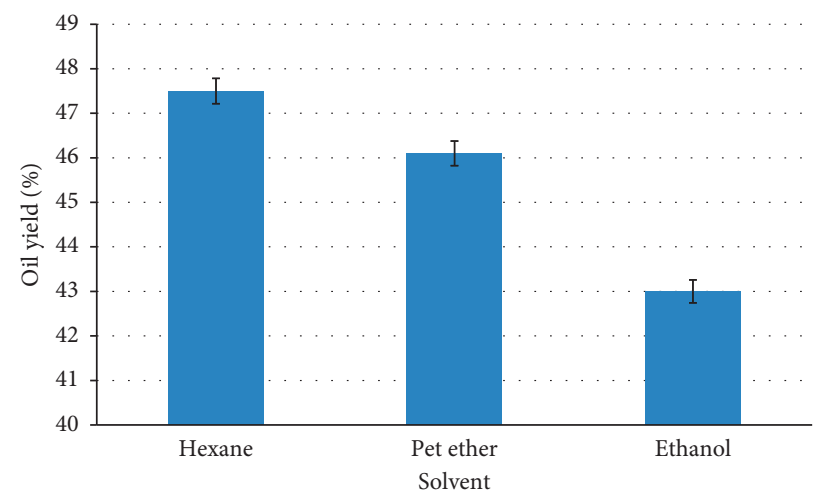

FIGURE 6: Effect of the type of solvent on oil recovery.

TABLE 1: Some of the important parameters of the solvents studied at $25^{\circ} \mathrm{C}$.

\begin{tabular}{lcccc}
\hline Solvent & $\begin{array}{c}\text { Density } \\
\left(\mathrm{g} / \mathrm{cm}^{3}\right)\end{array}$ & $\begin{array}{c}\text { Dynamic viscosity } \\
(\mathrm{mPa} . \mathrm{s})\end{array}$ & $\begin{array}{c}\text { Dielectric } \\
\text { constant }\end{array}$ & Polarity \\
\hline n-Hexane & 0.6606 & 0.30 & 1.88 & Nonpolar \\
$\begin{array}{l}\text { Petroleum } \\
\text { ether }\end{array}$ & 0.653 & 0.46 & 1.90 & Nonpolar \\
Ethanol & 0.785 & 1.074 & 24.60 & Polar \\
\hline
\end{tabular}

The higher oil yield $(47.5 \% \mathrm{w} / \mathrm{w})$ corresponding to an oil recovery of $98.6 \% \mathrm{w} / \mathrm{w}$ suggest that $\mathrm{n}$-hexane is a favorable solvent for the extraction of Jatropha oil followed by petroleum ether with an oil yield of $46.2 \% \mathrm{w} / \mathrm{w}$ (oil recovery of $95.8 \% \mathrm{w} / \mathrm{w}$ ) and ethanol with an oil yield of $43.0 \mathrm{w} / \mathrm{w}$ (oil recovery of $89.2 \% \mathrm{w} / \mathrm{w}$ ) (Figure 6).

3.7. Oil Characterization. In this study, the optimal conditions were observed to be solvent-to-solid ratio of $6: 1$, range of particle size of $0.5-0.8 \mathrm{~mm}$, extraction time of $7 \mathrm{~h}$, hexane as solvent, and extraction temperature of $68^{\circ} \mathrm{C}$ (boiling point of hexane). These parameters were used for the preparation of $10 \mathrm{~L}$ of Jatropha oil that was subjected to characterization, and the results are presented in Table 2 along with a comparison with literature values.

It can be seen in Table 2 that, with the exception of the pour point, the rest of the quality parameters investigated are within the ranges of the similar oil reported in the literature, suggesting that the oil produced was of acceptable quality. The pour point measured in this study appear to be not in agreement with the range reported in the literature, and this might have been due to geographical location (climate and altitude), soil fertility where the plant under study comes from, the species, and the oil extraction method used $[26,27,32]$. This can also be due to a variety (70-175) of species of Jatropha including the J. curcas, J. pohliana, and J. gossypiifolia that produce seeds with high oil content [27]. It is therefore evident that the quality parameters of the oil extracted from these variety of species may differ. However, it is exemplified in this study that the oil extracted has qualities (Table 2) that are potential for using it in biodiesel production, thus providing a positive contribution to the energy sector.
3.8. Viability of the Solvent. Jatropha oil extraction using hexane has been found to be favorable in this work; however, its characteristics such as flammability, volatility, toxicity, negative impact on environment, operational safety, and possible residues after refining are drawbacks to its application [37-41]. In addition, hexane and petroleum ether are solvents that are derived from petroleum resources that are not renewable. These observations pose a great challenge to the viability of these solvents. Other solvents such as isopropanol and ethyl acetate have been examined in the literature for the extraction of oil from oil bearing resources, and they are plausible for further investigations as they have shown promising results [40,41]. Ethanol, on the other hand, is considered as a green solvent with low toxicity and good operational safety and biodegradable, and most importantly, it can be obtained from renewable resources through the fermentation of biomass [40]. The extraction of oil with ethanol is said to be an appropriate route when the oil obtained is to be used for the production of biodiesel since the reaction (transesterification) at appropriate temperature and time can be performed in a single stage [40]. The comparison of oil yields of ethanol extraction obtained in this study with literature values for various materials are presented in Table 3. From this table, it can be seen that the oil yield obtained in this study using ethanol (43\%) compares well with those reported in the literature (25-49.2\%) for similar materials. In addition, the improvement of the extraction method such as using ultrasound-assisted extraction (UAE) and pressurized liquid ethanol appear to be potential methods for further investigations as they provide improved yields. In addition, these methods seem to reduce the extraction time (19-120 $\mathrm{min})$ as compared to $7 \mathrm{~h}$ for conventional Soxhlet extraction (Table 3), suggesting noble technological viability. 
TABLE 2: Comparison of Jatropha oil quality parameters obtained in this study with those in the literature.

\begin{tabular}{|c|c|c|c|}
\hline S. no. & Parameter & This study & From literature \\
\hline 1 & Moisture content $(\% \mathrm{w} / \mathrm{w})$ & 0.05 & $0.04-0.159[17,31]$ \\
\hline 2 & Density $\left(\mathrm{kg} / \mathrm{m}^{3}\right)\left(15^{\circ} \mathrm{C}\right)$ & 907 & $890-926[31,32]$ \\
\hline 3 & Acid value $(\mathrm{mg} \mathrm{KOH} / \mathrm{g})$ & 0.53 & $0.92-6.16[10,32]$ \\
\hline 4 & Free fatty acid (FFA) (\%) & 0.27 & $0.18-3.4[26]$ \\
\hline 5 & Saponification value $(\mathrm{mg} \mathrm{KOH} / \mathrm{g})$ & 195 & $190-213[26,31,32]$ \\
\hline 6 & Pour point $\left({ }^{\circ} \mathrm{C}\right)$ & -6 & $1-5[26,32]$ \\
\hline 7 & Cloud point $\left({ }^{\circ} \mathrm{C}\right)$ & -4 & $-9-6[32]$ and $8-10[26]$ \\
\hline 8 & Flash point $\left({ }^{\circ} \mathrm{C}\right)$ & 149 & $130-240[31,32]$ \\
\hline 9 & Iodine no. $(\mathrm{g} / 100 \mathrm{~g})$ & 101 & $84-115[26,31-33]$ \\
\hline 10 & Kinematic viscosity $\left(\mathrm{mm}^{2} / \mathrm{s}\right)\left(40^{\circ} \mathrm{C}\right)$ & 31.5 & $17-46[31,32,34]$ \\
\hline 11 & Calorific value $(\mathrm{MkJ} / \mathrm{kg})$ & 39.6 & $37.83-42.05[26,32,35]$ \\
\hline 12 & Cetane number & 23 & $23-56[32,33,36]$ \\
\hline 13 & Oxidation stability (min) & 175 & $179[31]$ \\
\hline
\end{tabular}

TABLE 3: Comparison of oil yield obtained using ethanol extraction from various materials.

\begin{tabular}{|c|c|c|c|c|c|}
\hline S. no. & Materials/seeds used & Extraction method & Optimal conditions & $\%$ yield & Reference \\
\hline 1 & Favela seeds & $\begin{array}{l}\text { Pressurized liquid } \\
\text { ethanol at } 10 \mathrm{MPa}\end{array}$ & $\begin{array}{l}\text { Ethanol consumed: } 58 \mathrm{~g} \text {, } \\
19 \text { min of dynamic extraction }\end{array}$ & 45.8 & {$[37]$} \\
\hline 2 & Macauba fruit & $\begin{array}{l}\text { Ultrasound-assisted } \\
\text { extraction (UAE) }\end{array}$ & $70^{\circ} \mathrm{C}, 45 \mathrm{~min}$ & 37.95 & {$[38]$} \\
\hline 3 & Flax seeds & Orbital shaker & $60^{\circ} \mathrm{C}, 120 \mathrm{~min}, 12 \mathrm{mLg}^{-1}$ & $\begin{array}{l}70 \% \text { of classical } \\
\text { extraction }\end{array}$ & [39] \\
\hline 4 & Raddish seeds & UAE & $60^{\circ} \mathrm{C}, 60 \mathrm{~min}, 12 \mathrm{mLg}^{-1}$ & 25 & {$[40]$} \\
\hline 5 & Macauba pulp & UAE & $60^{\circ} \mathrm{C}, 90 \mathrm{~min}, 10 \mathrm{mLg}^{-1}$ & 49.2 & {$[41]$} \\
\hline 6 & Chia seeds & UAE & $50^{\circ} \mathrm{C}, 40 \mathrm{~min}, 12 \mathrm{mLg}^{-1}$ & 27.24 & {$[42]$} \\
\hline 7 & Jatropha seeds & Soxhlet & $70^{\circ} \mathrm{C}, 7 \mathrm{~h}, 6: 1$ & 43.0 & This work \\
\hline
\end{tabular}

\section{Conclusion}

From this study, it has been found that the oil content of the Jatropha curcas L. seeds used was $48.2 \pm 0.12 \% \mathrm{w} / \mathrm{w}$. The results also confirm that $\mathrm{n}$-hexane is a suitable solvent for the extraction of Jatropha oil and the optimal conditions are as follows: solvent-to-solid ratio of $6: 1$, particle size of $0.5-0.8 \mathrm{~mm}$, extraction time of $7 \mathrm{~h}$, and extraction temperature of $68^{\circ} \mathrm{C}$, and the oil yield was $47.5 \pm 0.11 \% \mathrm{w} / \mathrm{w}$ corresponding to an oil recovery of $98.6 \pm 0.3 \% \mathrm{w} / \mathrm{w}$. This was followed by petroleum ether and lastly by ethanol. The quality parameters of the oil extracted compared favorably well with most of the values reported in the literature, suggesting that the oil was of good quality for biodiesel production. Environmental and safety concerns pose great challenge on viability of hexane in industrial scale solvent extraction of the oil. In this regard, ethanol which is an environmentally friendly solvent that can be produced from renewable biomass is recommended for application. The optimal conditions for ethanol extraction obtained in this study are as follows: extraction temperature of $70^{\circ} \mathrm{C}$, extraction time of $7 \mathrm{~h}$, solvent-to-solid ratio of $6: 1$, and particle size of $0.5-0.8 \mathrm{~mm}$, and oil yield of $43 \pm 0.18 \% \mathrm{w} / \mathrm{w}$ corresponding to an oil recovery of $89.2 \pm 0.4 \%$ w $/ w$.

\section{Data Availability}

The data used to support the findings of this study are available from the corresponding author upon request.

\section{Disclosure}

This research was performed as part of the employment activities of the author by the University of Dodoma.

\section{Conflicts of Interest}

The author hereby declares no conflicts of interest with the work under consideration.

\section{Acknowledgments}

The author sincerely acknowledges the logistical support offered by Nelson Mandela African Institution of Science and Technology (NM-AIST), Tengeru, Arusha, Tanzania, during his sabbatical leave and preparation of this work.

\section{References}

[1] T. Ahmad and D. Zhang, "A critical review of comparative global historical energy consumption and future demand: the story told so far,” Energy Reports, vol. 6, pp. 1973-1991, 2020.

[2] T. Kober, H.-W. Schiffer, M. Densing, and E. Panos, "Global energy perspectives to 2060 - WEC's world energy scenarios 2019," Energy Strategy Reviews, vol. 31, Article ID 100523, 2020.

[3] Statistical Review of World Energy (2020) (PDF). https://www. bp.com/content/dam/bp/business-sites/en/global/corporate/ pdfs/energy-economics/statistical-review/bp-stats-review-2020full-report.pdf Retrieved 13 April 2021. 
[4] A. S. Elgharbawy, W. A. Sadik, O. M. Sadek, and M. A. Kasaby, "A review on biodiesel feedstocks and production technologies," Journal of the Chilean Chemical Society, vol. 66, no. 1, pp. 5098-5109, 2021.

[5] L. E. Rincón, J. J. Jaramillo, and C. A. Cardona, "Comparison of feedstocks and technologies for biodiesel production: an environmental and techno-economic evaluation," Renewable Energy, vol. 69, pp. 479-487, 2014.

[6] M. Jonas, C. Ketlogetswe, and J. Gandure, "Variation of Jatropha curcas seed oil content and fatty acid composition with fruit maturity stage," Heliyon, vol. 6, no. 1, Article ID e03285, 2020.

[7] A. V. Yate, P. C. Narváez, A. Orjuela, A. Hernández, and H. Acevedo, "A systematic evaluation of the mechanical extraction of Jatropha curcas L. oil for biofuels production," Food and Bioproducts Processing, vol. 122, pp. 72-81, 2020.

[8] E. Akbar, Z. Yaakob, S. Kamarudin, M. Ismail, and J. Salimon, "Characteristic and composition of Jatropha curcas oil seed from Malasia snd its potential as biodiesel feedstock," European Journal of Scientific Research, vol. 29, pp. 396-403, 2009.

[9] S. Jain, "The production of biodiesel using Karanja (Pongamia pinnata) and Jatropha (Jatropha curcas) Oil," Biomass, Biopolymer-Based Materials, and Bioenergy, vol. 1, pp. 397-408, 2019.

[10] M. A. Fazal Um, "Comparative analysis of physical and chemical properties of jatropha oil,"Bulletin of The transilvania University of Braşov, vol. 8, no. 57, 1, pp. 37-42, 2015.

[11] P. Willems, N. J. M. Kuipers, and A. B. De Haan, "Hydraulic pressing of oilseeds: experimental determination and modeling of yield and pressing rates," Journal of Food Engineering, vol. 89, no. 1, pp. 8-16, 2008.

[12] A. Chapuis, J. Blin, P. Carré, and D. Lecomte, "Separation efficiency and energy consumption of oil expression using a screw-press: the case of Jatropha curcas L. seeds," Industrial Crops and Products, vol. 52, pp. 752-761, 2014.

[13] E. Subroto, R. Manurung, H. J. Heeres, and A. A. Broekhuis, "Mechanical extraction of oil from Jatropha curcas L. kernel: effect of processing parameters," Industrial Crops and Products, vol. 63, pp. 303-310, 2015.

[14] P. Evon, I. Amalia Kartika, M. Cerny, and L. Rigal, "Extraction of oil from Jatropha seeds using a twin-screw extruder: feasibility study," Industrial Crops and Products, vol. 47, pp. 33-42, 2013.

[15] M. Baldini, E. Bulfoni, and C. Ferfuia, "Seed processing and oil quality of Jatropha curcas L. on farm scale: a comparison with other energy crops," Energy for Sustainable Development, vol. 19, pp. 7-14, 2014.

[16] S. Romuli, S. Karaj, S. Latif, and J. Müller, "Performance of mechanical co-extraction of Jatropha curcas L. kernels with rapeseed, maize or soybean with regard to oil recovery, press capacity and product quality," Industrial Crops and Products, vol. 104, pp. 81-90, 2017.

[17] S. Karaj and J. Müller, "Optimizing mechanical oil extraction of Jatropha curcas $L$. seeds with respect to press capacity, oil recovery and energy efficiency," Industrial Crops and Products, vol. 34, no. 1, pp. 1010-1016, 2011.

[18] S. Karaj and J. Müller, "Temperature influence on chemical properties of jatropha curcas L. oil extracted with mechanical screw press," Biofuels, vol. 12, no. 7, pp. 853-859, 2019.

[19] S. Shah, A. Sharma, and M. N. Gupta, "Extraction of oil from Jatropha curcas L. seed kernels by combination of ultrasonication and aqueous enzymatic oil extraction," Bioresource Technology, vol. 96, no. 1, pp. 121-123, 2005.
[20] K. Valladares-Diestra, L. P. de Souza Vandenberghe, and C. R. Soccol, "Oilseed enzymatic pretreatment for efficient oil recovery in biodiesel production industry: a review," BioEnergy Research, vol. 13, no. 4, pp. 1016-1030, 2020.

[21] D. Nde and A. Foncha, "Optimization methods for the extraction of vegetable oils: a review," Processes, vol. 8, no. 2, p. 209, 2020.

[22] S. Y. Adeyinka, "Parametric optimization of solvent extraction of Jatropha curcas seed oil using design of experiment and its quality characterization," South African Journal of Chemical Engineering, vol. 35, pp. 60-68, 2021.

[23] J. Qian, H. Shi, and Z. Yun, "Preparation of biodiesel from Jatropha curcas $L$. oil produced by two-phase solvent extraction," Bioresource Technology, vol. 101, no. 18, pp. 7025-7031, 2010.

[24] Y. G. Keneni, L. A. Bahiru, and J. M. Marchetti, "Effects of different extraction solvents on oil extracted from jatropha seeds and the potential of seed residues as a heat provider," BioEnergy Research, vol. 5, pp. 1-16, 2020.

[25] A. E. Atabani, A. S. Silitonga, I. A. Badruddin, T. M. I. Mahlia, H. H. Masjuki, and S. Mekhilef, "A comprehensive review on biodiesel as an alternative energy resource and its characteristics," Renewable and Sustainable Energy Reviews, vol. 16, no. 4, pp. 2070-2093, 2012.

[26] D. Singh, D. Sharma, S. L. Soni et al., "A comprehensive review of physicochemical properties, production process, performance and emissions characteristics of 2 nd generation biodiesel feedstock: jatropha curcas," Fuel, vol. 285, Article ID 119110, 2021

[27] S. A. Ceaser and S. Ignacimuthu, "Applications of biotechnology and biochemical engineering for improvement of Jatropha and biodiesel: a review," Renewable and Sustainable Energy Reviews, vol. 15, pp. 5176-5185, 2011.

[28] S. Sayyar, Z. Z. Abidin, and R. Yunus, "Optimisation of solid liquid extraction of Jatropha oil using petroleum Ether," AsiaPacific Journal of Chemical Engineering, vol. 8, no. 3, pp. 331-338, 2012.

[29] A. S. Yusuff, "Parametric optimization of solvent extraction of Jatropha curcas seed oil using design of experiment and its quality characterization," South African Journal of Chemical Engineering, vol. 35, pp. 60-68, 2021.

[30] H. E. Zimilar, J. S. Mandlate, E. M. Artur, H. F. Muiambo, and A. A. Uamusse, "Vortex-assisted solid-liquid extraction for rapod screening of oil content in Jatropha seed: an alternative to the modified soxhlet method," South African Chemical Institute, vol. 75, pp. 1-5, 2021.

[31] A. Yadav and V. Krishna, "Sustainable energy production from Jatropha bio-diesel," International Journal of Advancements in Research and Technology, vol. 1, no. 5, pp. 1-6, 2012.

[32] G. A. Ewunie, J. Morken, O. I. Lekang, and Z. D. Yigezu, "Factors affecting the potential of Jatropha curcas for sustainable biodiesel production: a critical review," Renewable and Sustainable Energy Reviews, vol. 137, Article ID 110500, 2021.

[33] M. Mofijur, H. H. Masjuki, M. A. Kalam et al., "Prospects of biodiesel from jatropha in Malaysia," Renewable and Sustainable Energy Reviews, vol. 16, no. 7, pp. 5007-5020, 2012.

[34] A. Demirbas, A. Bafail, W. Ahmad, and M. Sheikh, "Biodiesel production from non-edible plant oils," Energy Exploration \& Exploitation, vol. 34, no. 2, pp. 290-318, 2016.

[35] I. Golshokouh, M. Golshokouh, F. N. Ani, E. Kianpour, and S. Syahrullail, "Investigation of physical properties for jatropha oil in different temperature as lubricant oil," Life Science Journal, vol. 10, no. 8, 2013. 
[36] R. K. Singh and S. K. Padhi, "Characterization of Jatropha oil for the preparation of biodiesel," Natural Product Radiance, vol. 8, no. 2, pp. 127-132, 2009.

[37] K. A. Santos, C. M. de Aguiar, E. A. da Silva, and C. da Silva, "Evaluation of favela seed oil extraction with alternative solvents and pressurized-liquid ethanol," The Journal of Supercritical Fluids, vol. 169, Article ID 105125, 2021.

[38] A. C. S. da Rosa, N. Stevanato, V. A. dos Santos Garcia, and C. da Silva, "Simultaneous extraction of the oil from the kernel and pulp of macauba fruit using a green solvent," Journal of Food Processing and Preservation, vol. 44, no. 11, Article ID e14855, 2020.

[39] C. D. P. Laidens, N. Postaue, N. Stevanato, and C. D. Silva, "Extração a baixa pressão do óleo de sementes de linhaça utilizando etanol como solvente," E-Xacta, vol. 12, no. 2, pp. 1-10, 2020.

[40] N. Stevanato and C. da Silva, "Radish seed oil: Ultrasoundassisted extraction using ethanol as solvent and assessment of its potential for ester production," Industrial Crops and Products, vol. 132, pp. 283-291, 2019.

[41] G. d. M. Rodrigues, B. T. F. d. Mello, V. A. dos Santos Garcia, and C. d. Silva, "Ultrasound-assisted extraction of oil from macauba pulp using alcoholic solvents," Journal of Food Process Engineering, vol. 40, no. 5, Article ID e12530, 2017.

[42] B. T. F. De Mello, V. A. dos Santos Garcia, and C. da Silva, "Ultrasound-assisted extraction of oil from chia (salvia hispânica L.) seeds: optimization extraction and fatty acid profile," Journal of Food Process Engineering, vol. 40, no. 1, Article ID e12298, 2015. 